\title{
Progressive evolution of thyroid adenoma to thyroid carcinoma
}

\author{
Aisyah Elliyanti \\ Medical Physics Department, Faculty of Medicine, Universitas Andalas/Nuclear Medicine Division of \\ Department of Radiology Dr. M. Djamil Hospital, Padang, Indonesia
}

Correspondence: Aisyah Elliyanti, email: aelliyanti@med.unand.ac.id

\begin{abstract}
Nodules (adenomas), enlarged thyroid (goiter) and inflammation of the thyroid (thyroiditis) are the most important risk factors for thyroid cancer. Adenomas have the largest increase in risk. Objectives: to discuss two cases of adenomas goiter that became aggressive during follow-ups. Cases: Two patients, with an average age of 64 years, referred to Nuclear Medicine dr. M. Djamil Hospital in Padang for bone scintigraphy examination. Both patients had thyroid surgery and histopathology results were adenomas. However, after the removal surgery, the patients did not have proper followups. Both patients developed pelvic pain. Bone scintigraphy showed an increase of radiopharmaceutical uptake at pelvic bones and computerized tomography (CT Scan) result showed destruction at the pelvic bone areas. Conclusions: These cases highlight the necessity for adenoma thyroid patients with a risk factor for thyroid cancer to have a complete follow-up program and sufficient length period.
\end{abstract}

Keyword: thyroid cancer; bone metastasis; scintigraphy; thyroglobulin

\section{Abstrak}

Nodul (adenoma), pembesaran kelenjar tiroid (goiter) dan radang tiroid (tiroiditis) merupakan faktor risiko terjadinya kanker tiroid. Adenoma merupakan risiko terbanyak terjadinya kanker tiroid. Tujuan: Untuk membahas dua kasus adenoma tiroid yang menjadi agresif dikemudian hari. Kasus: Dua pasien, dengan usia rata-rata 64 tahun, dirujuk ke Kedokteran Nuklir Rumah Sakit dr. M. Djamil di Padang untuk pemeriksaan scintigraphy tulang. Kedua pasien menjalani operasi tiroid dan hasil histopatologi adalah adenoma. Namun, setelah operasi pengangkatan, pasien tidak melakukan pemeriksaan berkala sebagaimana mestinya. Kedua pasien datang dengan keluhan nyeri panggul. Scintigraphy tulang menunjukkan peningkatan tangkapan radiofarmaka pada tulang-tulang di pelvis. Hasil pemeriksaan computerized tomography (CT Scan) menunjukkan kerusakan pada daerah tulang panggul. Simpulan: Perlu digaris bawahi bahwa pasien adenoma tiroid yang memiliki faktor risiko kanker tiroid perlu melakukan pemeriksaan berkala sebagai tindak lanjut setelah operasi.

Kata kunci: kanker tiroid; metastasis pada tulang; scintigraphy; tiroglobulin 


\section{INTRODUCTION}

Adenoma of the thyroid are typically discrete, solitary masses. It derived from follicular epithelium and be called as follicular adenomas. Adenoma is classified on the basis of degree of follicle formation and the colloid content of the follicles. ${ }^{1,2}$ Follicular epithelium cell origin account for majority of thyroid cancer. ${ }^{3}$ Nodules (adenomas), enlarged thyroid (goiter) and inflammation of thyroid (thyroiditis) are the most important risk factors for thyroid cancer. One of five of thyroid cancer cases (20\%) has non-cancerous of thyroid history. ${ }^{4,5}$ Having adenomas history that be started particularly at young age is a risk factor that can lead to be a cancer. ${ }^{6,7}$ The aim of this study is to discuss two cases of adenomas goiter that became aggressive during follow-ups.

\section{CASES}

\section{Case Report 1}

A 66-year-old woman had a pelvic bone pain, when she referred to a Nuclear Medicine from Orthopedic clinics at dr. M. Djamil Hospital. She had a thyroid surgery 9 years before, and histopathology result was adenomatous goiter. After the removal surgery, she did not do follow-ups. The CT scan result showed a multiple bone destruction with a bone metastases impression at left anterior superior iliac spine and left superior pubic ramus (Figure 1).

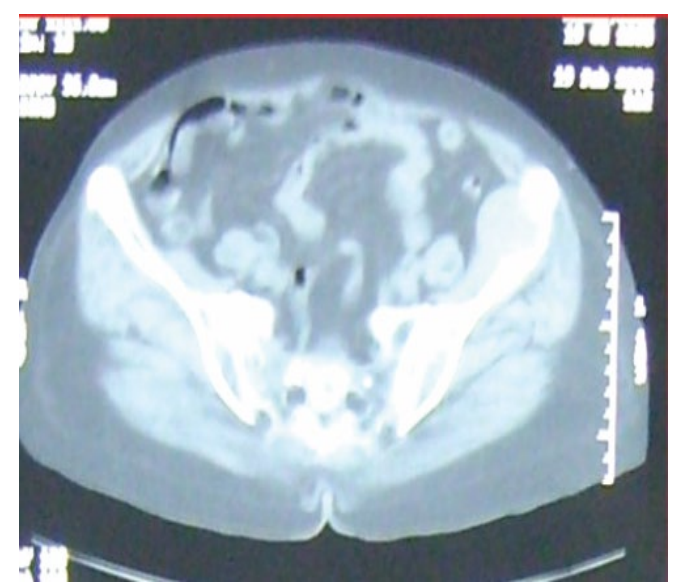

(a)

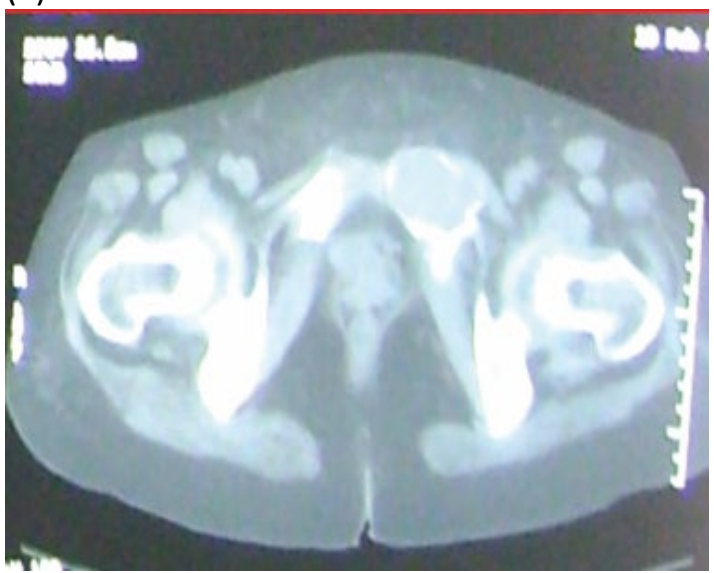

(b)

Figure 1. Bone destruction at left anterior superior iliac spine (a) and at left superior pubic ramus (b).

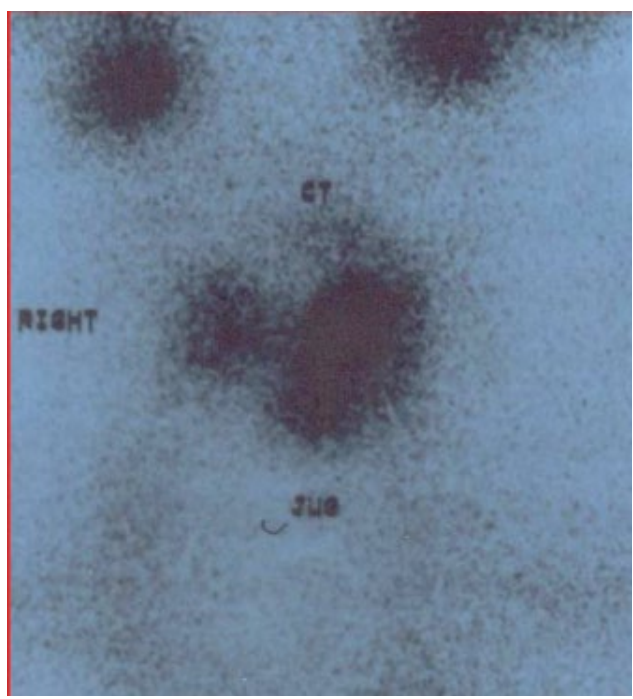

Figure 2. Thyroid scintigraphy showed a thyroid remnant. 
The thyroid scintigraphy showed a residual thyroid tissue (Figure 2). Bone scintigraphy demonstrated an increased uptake at vertebrae lumbar IV-V, left anterior superior iliac spine and left superior pubic ramus (Figure 3 ). The thyroglobulin serum was $2 \mu \mathrm{g} / \mathrm{L}$ and TSH was $1.23 \mu \mathrm{lU} / \mathrm{mL}$. She received radioiodine (Nal-131) $80 \mathrm{mCi}$ $\left(2.96 \times 10^{3} \mathrm{MBq}\right)$ and post therapy scan show a high uptake of $\mathrm{I}-131$ at pelvic bones.

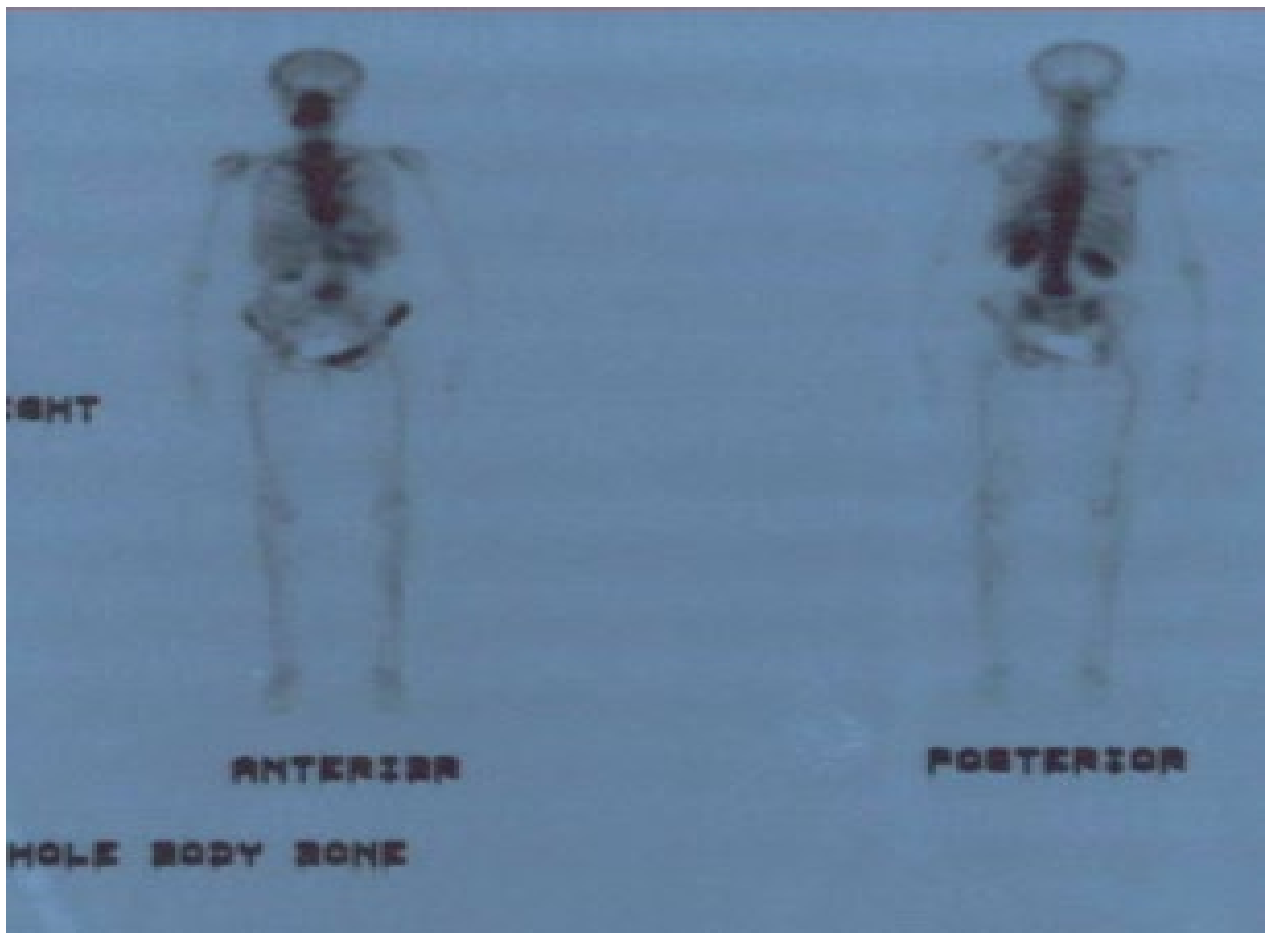

Figure 3. Bone scan showed a high uptake at lumbar spine IV-V and left anterior iliac spine and left superior pubic ramus.

\section{Case Report 2}

A 62-year-old woman had the right hip join complain. She referred to our department for bone scintigraphy. She had lobectomy five years ago with adenomatous goiter histopathology result. The radiology $\mathrm{x}$-ray showed a destruction at head of right femur and it assumed as a metastases process. She did not have a proper followup. The bone scintigraphy showed high uptakes at head of right femur and pelvic (ilio-pubic imminence and acetabulum) (Figure 4). The thyroglobulin serum was 89 $\mu \mathrm{g} / \mathrm{L}$ and TSH was $0.571 \mu \mathrm{lU} / \mathrm{mL}$. 


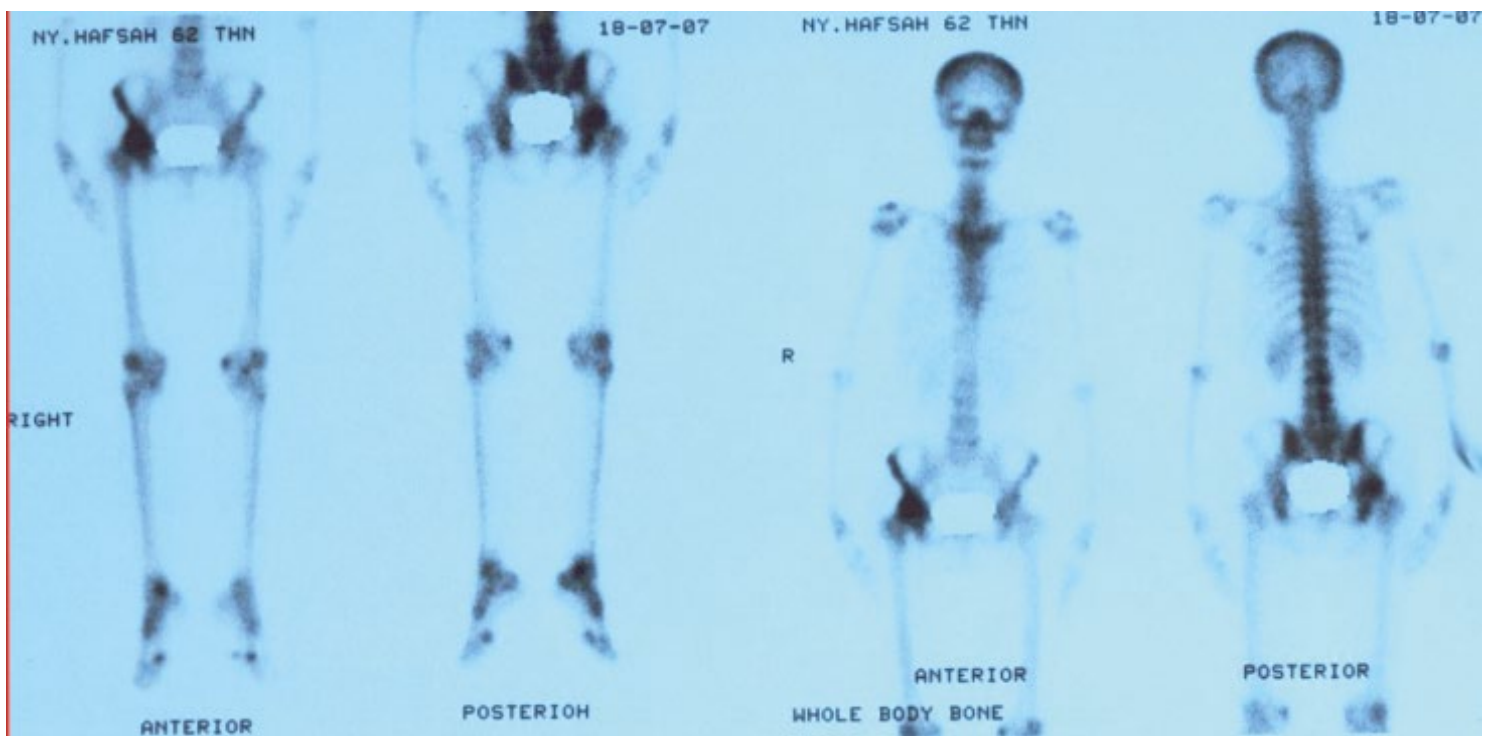

Figure 4. The bone scintigraphy showed high uptakes at head of right femur and right pelvic (iliopubic imminence and acetabulum).

\section{DISCUSSIONS}

The morphologic diagnosis of the thyroid neoplasms is subject to pathologist interpretation in specific architecture and cytology features. Certain anatomic features may suggest innocence, whereas other point toward cancerous potential. Follicular adenoma and follicular carcinoma cannot distinguish by cytology alone. ${ }^{8}$ Ultimately, morphologic diagnosis cannot predict the biologic behaviour where the prediction is confounded by a marked discrepancy between the morphologic appearance of a tumour and its behaviours. Occasionally, miss classification but on the other hand, thyroid carcinomas can develop from adenomas. ${ }^{4,6}$

In general, benign tumours are welldifferentiated and certain welldifferentiated thyroid cancer may form normal-appearing follicles. Thus, morphologic diagnosis of a welldifferentiated thyroid tumour may sometimes quite difficult. ${ }^{6,8}$ Furthermore, the highest frequency of RAS mutation in follicular adenomas and carcinomas suggests that the two may be related tumor. ${ }^{3,9}$ About $48 \%$ of follicular adenomas have point mutations in the RAS family of oncogenes, which have also been identified in $57 \%, 21 \%$ of follicular thyroid carcinoma and papillary thyroid carcinoma respectively. ${ }^{3}$ Progressive changing from follicular adenoma to follicular carcinoma can be explained by firstly, RAS mutation and PAX8-PPARY rearrangements. Secondly, mRNA profiles regulate both tumors mostly in common and dominant genes in carcinomas are further amplified. ${ }^{7}$ These conditions raise the possibility that some adenomas may progress to carcinomas.

The aggressiveness of particular morphologic type of thyroid neoplasm 
remains unpredictable in the individual case. An appropriate follow-up protocol with benign thyroid morphologic is important for determining their likelihood of developing cancer and a follow-up study of each neoplasm can establish the level of risk. It should be reminded that the cancer can arise from a non-malignant cell in the benign tumour or the benign tumour contain silent or indolent malignant focus. In two cases above, changing behaviour of adenomatous goiter can arise from normal-appearing follicles of nonmalignant cell.

\section{CONCLUSIONS}

Certain well-differentiated thyroid cancer may form normal-appearing follicles. This case highlights, that follow-ups should be complete, detailed and sufficient length for patients with risk factor for thyroid cancer.

\section{REFERENCES}

1. Cotran R, Kumar V, Collins T. Robbins Pathologic Basis of Disease. 6th Edition. Philadelphia: Saunders; 1999.

2. Katoh H, Yamashita K, Enomoto T, Watanabe M. Classification and General Considerations of Thyroid Cancer. Ann Clin Pathol. 2015; 3(1):1045. [Abstract/FREE Full Text].

3. Howell GM, Hodak SP, Yip L. RAS Mutations in Thyroid Cancer. Oncologist. 2013; 18(8):926-932. doi: 10.1634/theoncologist.2013-0072. [PMC free article].

4. Hoang J. Thyroid nodules and evaluation of thyroid cancer risk. Australas J Ultrasound Med. 2010; 13(4):33-36. doi: 10.1002/j.2205-0140.2010.tb00177.x. [PMC free article].

5. Kust D, Mateša N, Kusić Z. Clinical Significance of Multi-nodular in Patients with Papillary Thyroid Carcinoma. Anticancer Res. 2015; 35(11):6335-9. [PubMed] [Abstract/FREE Full Text].

6. Dom G, Frank S, Floor S, Kehagias P, Libert F, Hoang C, et al. Thyroid follicular adenomas and carcinomas: molecular profiling provides evidence for a continuous evolution. Oncotarget. 2018; 9(12):10343-10359. doi: 10.18632/oncotarget.23130. [PMC free article].

7. Gupta N, Dasyam AK, Carty SE, Nikiforova MN, Ohori NP, Amstrong M, et al. RAS mutations in thyroid FNA specimens are highly predictive of predominantly low-risk follicular-pattern cancers. J Clin Endorinol Metab. 2013; 98(5):E914-22. doi: 10.1210/jc.2012-3396. [PubMed].

8. McHenry CR, Phitayakorn R. Follicular Adenoma and Carcinoma of Thyroid Gland. Oncologist. 2011; 16(5):585-593. doi: 10.1634/theoncologist.2010-0405. [PMC free article].

9. Xing M. Clinical utility of RAS mutations in thyroid cancer: a blurred picture now emerging clearer. BMC Med. 2016; 14:12. doi: 10.1186/s12916-016-0559-9. [PubMed]. 